\title{
The Impact of the Covid 19 Virus Pandemic on Tulamben Bali Dive Tour Visits
}

\author{
$1^{\text {st }}$ Vera Septi Sistiasih \\ Pendidikan Olahraga \\ Universitas Muhammadiyah \\ Surakarta \\ Surakarta, Indonesia \\ vss538@ums.ac.id \\ $4^{\text {th }}$ Muhad Fathoni \\ Pendidikan Olahraga \\ Universitas Muhammadiyah \\ Surakarta \\ Surakarta, Indonesia \\ mf378@ums.ac.id
}

\author{
$2^{\text {nd }}$ Nur Subekti \\ Pendidikan Olahraga \\ Universitas Muhammadiyah \\ Surakarta \\ Surakarta, Indonesia \\ ns584@ums.ac.id
}

$5^{\text {th }}$ Satrio Sakti Rumpoko
Pendidikan Jasmani
Universitas Tunas Pembangunan
Surakarta
Surakarta, Indonesia
saktirumpoko1@gmail.com

$3^{\text {rd }}$ Agam Akhmad Syaukani Pendidikan Olahraga

Universitas Muhammadiyah Surakarta

Surakarta, Indonesia

aas622@ums.ac.id

\author{
$6^{\text {th }}$ Rizka Nur Ariyanti Aliya \\ Pendidikan Olahraga \\ Universitas Muhammadiyah \\ Surakarta \\ Surakarta, Indonesia \\ a810170047@student.ums.ac.id
}

\begin{abstract}
The COVID-19 pandemic in Indonesia has yet to show a decrease in its spread. The latest data shows 2.98 million cases of covid 19. In dealing with the increasing spread of the covid 19 virus, the government has also overcome it by implementing Community Activity Restrictions (PPKM) throughout Java-Bali in July 2021 for 2 weeks. This certainly has a very pronounced impact on the economic sector because of the limited mobility of the community. One of the areas affected by this PPKM is diving tourism in Tulamben Bali. Due to this PPKM, the number of local and foreign tourists who come has decreased significantly. This research is a field survey research. Researchers collected data from divers in the Tulamben area, Bali.
\end{abstract}

Keywords-Covid 19, scuba diving, tulamben

\section{INTRODUCTION}

The Covid-19 pandemic in Indonesia is part of the 2019 coronavirus pandemic (Covid-19) that is toasting around the world. Positive cases of Covid-19 in Indonesia were first detected on March 2, 2020. In its development in dealing with the spread of pandemics in Indonesia, the government made some rules that were futures. In response to the pandemic, some regions have imposed Large-Scale Social Restrictions (PSBB) by 2020. This policy was replaced by the Enactment of Restrictions on Community Activities (PPKM) in 2021. In January 2021 the government started the Covi-19 vaccination program in Indonesia. With the PPKM (Restriction of Community Activities) has an impact on the economic sector, as well as the economy in Bali. The largest contributor to economic income in Bali through the tourism sector, one of which is diving / diving tourism. Diving is a favorite tour of tourists, especially foreign tourists. According to tourists one of the diving tourist destinations that must be visited is diving tourism in Tulamben, Bali. But with the covid-19 pandemic, visitors in Tulamben decreased dramatically.

The word "tourism" comes from two syllables, namely pari and tourism. Pari yabf has many meanings, many times, circling while tourism means traveling or traveling. Tourism means traveling many times or traveling around. Tourism is the equivalent of the word Indonesian for the term tourism in English. (Mulyadi, 2009). The term tourism is closely related to travel as a change of residence while someone is out of place because of a reason and not to do activities that produce wages. Thus it can be said that a tourist trip is a trip 
made by someone or more with the aim of, among others, to get kenkmatan and fulfill the desire to know. It can also be due to interests related to sports activities for health, conventions, religion and other business purposes.

WTO (World Tourism Organization) and International Union of Office Travel Organization (IOUTO) define tourists as every visitor who stays as early as 24 hours and no more than 6 months with the purpose of: vacation, recreation, sports, business visiting friends and family. Tourism based on the understanding of the World Tourism and Travel Council (WTCC) is the entire life of people who travel to and live somewhere outside their daily environment for a period of no more than a year to relax, business and others. Pendit in Baruddin (2011) stated that tourism consists of activities such as cultural tourism, health tourism, culinary tourism, educational tourism, religious tourism, business tourism, industrial tourism, nature reserve tourism. Nautical tourism. Travel done by certain people will not happen if there is no underlying thing. There are things that encourage those people to travel wista. According to Mc Intosh in Suwena and Widyatmaja (2008) there are four motivations that encourage someone to do a tourism activity: (1). Motivation to meet physical needs: This motivation is related to refreshment of body and mind, health goals, exercise and fun. This motivation is related to all activities that serve to reduce all tension. (2) Motivation to get to know the culture: this motivation is identified with the desire to see and know more about the culture of other countries be it dances, how to dress, music, art and folklore. (3) Motivation to connect with others: The desire to meet new people, visit distant friends and family and seek out new, different experiences. Travel with tuuan to break away from routine relationships with friends and neighbors where they come from.

\section{Marine Tourism}

Marine tourism is all recreational activities whose activities are carried out on marine media and include coastal areas, surrounding islands and marine areas. As an island nation, Indonesia is endowed with outstanding marine tourism. Located within the triangular area of the world's coral reefs, the charm of Indonesian marine tourism can be seen from Sabang to Merauke. Marine tourism is all recreational activities whose activities are carried out in marine or marine media and include coastal areas, surrounding islands and marine areas in the sense of sea level, in the sea and seabeds and marine parks. These activities such as sky water, jet sky, swimming, speed boat, diving. For lovers of diving sports in Eastern Indonesia become prima donna. Call it Bali, Lombok, Maluku, Manado and of course Raja Ampat in West Papua.
One of the marine tourism destinations in which is very famous for the beauty of the underwater scenery is in Tulamben, Bali. Because the beauty of the underwater scenery makes Tulamben the best destination to do snorkeling and scuba diving activities on the island of Bali. The livelihoods of the people of Tulamben Village mostly as fishermen. There are also some who work as farmers, traders, construction workers, state workers and work in tourism. Tulamben Bali is a small village located northeast of the island of Bali. The location of Tulamben village overlooks the Lombok strait which is very rich in marine life. Tulamben village is included in the Kubu Subdistrict area in the northern part of Karangasem Regency, Bali.

Tulamben Bali is a small village located northeast of the island of Bali. The location of Tulamben village overlooks the Lombok strait which is very rich in marine life. Tulamben village is included in the kubu subdistrict, in the northern part of Karangasem-Bali regency. The development of Indonesian tourism and in Bali in particular, greatly helped the progress of Tulamben village. Proven by access road to the village of Tulamben so easy. Especially now that many inns are built in this area. Starting from jasmine hotels to star hotels with varying prices. Beachfront restaurants, merchants, masseurs, food and soft drink shops are very easy to find in this village.

Tulamben village as one of the tourist attractions in Bali, has its own uniqueness for water recreation on the island of Bali. The uniqueness of Tulamben village is found on the Liberty ship usat (US Army Transport) which sank in 1942. The USAT Liberty sank after being torpedoed by a Japanese submarine during World War II. The wreck of the USAT Liberty is at a depth of 30 meters from sea level and becomes the best diving spot in the village of Tulamben. From the coast, the distance of the wreck of the USAT Liberty is about 25 meters and usually divers will use the boat from the coast to the location of the wreck.

In the Tulamben area there are many interesting dive locations. Most of the dive area in Tulamben is on the southeast side. Diving and seeing the Wreck of liberty at Tulamben is a must if you like diving and are on vacation in Bali. At a depth of 30 meters, it will be able to clearly see the wreck of the USAT Liberty. The best time to dive at the USAT Liberty shipwreck site is around October and November.

\section{RESEARCH METHOD}

This research is conducted with descriptive research methods with a qualitative approach. Data collection is done by observation or observation, interview and documentation. This research is intended to explain the impact of the covid-19 pandemic on diving tourism in Tulamben, Karangasem, Bali. This research is intended to describe the circumstances, the multiplication of facts in the field. 


\section{A. Research Focus}

The focus of the research aims to limit the research to be more targeted and not deviate from the problem formulation. So in this study the focus of research from the subject matter is the impact of covid-19 on diving tourism in Tulamben, Karangasem, Bali.

\section{B. Research Location}

The location of this research is where the research will be conducted. The location that will be studied in this study is tulamben marine attraction, Karangasem, Bali.

\section{Types and Sources of Research Data}

Loflan and Lofland in Moloeng (2014: 157) the main data sources in qualitative research are words and actions, the rest are additional data such as documents and documentation and so on. Data is divided into two, namely primary data and secondary data. The two data are interrelated and are indispensable for obtaining relevant information and research needs.

\section{RESULTS AND DISCUSSION}

\section{A. The Impact Of The Pandemic On Diving Tourism}

Bali relies heavily on the tourism sector, before Covid-19 the tourism sector contributed up to $53 \%$ to the Economy of Bali. The influence of the Covid-19 pandemic is currently very significant impact over the Bali bombings and the eruption of Mount Agung. However, the economic recovery began to appear although very slowly since the opening of the new normal on a long holiday in late October, hotel room occupancy rates began to show an increase of about 25 $30 \%$, dominated by domestic or local tourists. Data shows that reaching $53 \%$ of Bali's economy is supported by the tourism sector. When viewed from the source of labor, it also has an impact that how much employment is absorbed from the tourism sector. To build jobs in Bali, the Provincial Government of Bali must revive Bali tourism. The impact of the Covid-19 pandemic on Bali's economy which is heavily dependent on the tourism sector is increasingly having a significant impact on the arrival of foreign tourists directly to Bali. In August 2020, the number of tourists was recorded at only 22 visits, down almost 100.00 percent $(-99,996$ percent) compared to the record number of foreign tourists in August 2019 which amounted to 606,412 visits. Judging from the decrease in foreign tourist visits also have an impact on diving tourism visits in Tulamben, Karangasem, Bali. Diving tourism is one of the tourism that is favored by the Balinese government, especially Tulamben, Karangasem. According to data from Conservation International (CI) Indonesia, visitors to Tulamben before the pandemic every day on average there were 200-400 divers enjoying the underwater beauty, in one year reaching 70,000 divers. Tourism in Tulamben is usually crowded in July-November, but in 2020 it is down almost $100 \%$. Apart from foreign tourists there are also domestic tourists. However, with the enactment of Restrictions on Community Activities (PPKM) in the Java-Bali region, domestic tourism is also reduced very drastically.

B. The Impact of The Pandemic On The Underwater Environment Of Tulamben

On the island of Bali, the impact of the Covid-19 pandemic had an impact on the tourism sector, which directly contributed to the decline in the volume of waste, especially in tourist areas. According to the Governor of Bali, Wayan Koster, the waste problem is a classic problem for Balinese people. The nature of the island of the Gods is damaged by garbage. Moreover, as a tourist destination, waste is also considered a scourge (merdeka.com, 2021). In addition to having an impact on the decline in visitors at Tulamben, the pandemic has an impact on the underwater environment. Tulamben is an area with black rocks, and some of the seabed is sandy. With the decrease in the number of divers, the condition of the coral reefs is getting better, the water also looks clearer.

\section{CONCLUSION}

Various efforts continue to be made in the hope that Bali will gain the trust of tourists as a worthy tourist destination to visit. This opportunity can only be achieved, as long as it can provide guarantees to tourists that conditions are safe from the risk of contracting Covid-19 while in Bali. Therefore, the implementation of health protocols in all sectors must be a shared focus. Economically and socially, from the data of Tulamben diving tourism visits from January to August 2020, it experienced almost $100 \%$ in addition to a decrease in the number of visits, the number of room/hotel occupancy, the number of uses of transportation and a decrease in income from related tourism businesses.

The development of tourism during the pandemic, which caused a slump, needs to be immediately addressed by the government by issuing policies holistically in dealing with this situation. As a result of the number of workers experiencing unemployment will certainly result in an increase in the number of poverty rates in Bali.

\section{REFERENCES}

[1] Arifin, Z., Yulianda, F., \& Imran, Z. (2019). ANALISIS KEANEKARAGAMAN BIOTA LAUT SEBAGAI DAYA TARIK WISATA UNDERWATER MACRO PHOTOGRAPHY (UMP) DI PERAIRAN 
TULAMBEN, BALI. Jurnal Ilmu dan Teknologi Kelautan Tropis, 11(2), 335-346.

[2] Ari, N. K., Atmadja, N. B., \& Purnawati, D. M. O. (2016). Sejarah Wisata Bahari dan Pendidikan Sadar Wisata pada Komunitas Desa (Studi Kasus di Desa Tulamben, Kubu, Karangasem, Bali). Widya Winayata: Jurnal Pendidikan Sejarah, 4(1).

[3] Ihsan, Y. N. (2021). DAMPAK COVID-19 TERHADAP SUMBER DAYA DAN KESEHATAN LAUT. UU No. 28 Tahun 2014 tentang Hak Cipta Fungsi dan Sifat Hak Cipta Pasal 4, 43.

[4] Jannah, H. R., \& Suryasih, I. A. (2019). Pengelolaan Desa Wisata Berbasis Masyarakat di Desa Mas, Ubud. Jurnal Destinasi Pariwisata, 7(1), 77-81.

[5] Nasution, D. A. D., Erlina, E., \& Muda, I. (2020). Dampak pandemi Covid-19 terhadap perekonomian Indonesia. Jurnal Benefita, 5(2), 212-224.

[6] Paramita, I. B. G., \& Putra, I. G. G. P. A. (2020). New Normal Bagi Pariwisata Bali Di Masa Pandemi Covid 19. Pariwisata Budaya: Jurnal Ilmiah Agama Dan Budaya, 5(2), 5765.

[7] Sari, N. A., Putra, I. N., \& Dirgayusa, I. P. (2017). Kajian Kesesuaian Wisata Selam dan Snorkeling di Perairan Tulamben Karangasem Bali. Journal of Marine and Aquatic Sciences, 3(1), 99-114.

[8] Soetanto, A. A. (2002). Hotel resor lepas pantai dan klub selam di Tulamben Bali (Doctoral dissertation, Petra Christian University).

[9] Sukana, M., Umiarti, A. T., \& Ariana, N. PENINGKATAN KINERJA LAYANAN PARIWISATA DAN PEMBERDAYAAN PEREMPUAN DI DESA TULAMBEN, KECAMATAN KUBU, KABUPATEN KARANGASEM. 